\title{
Праз болькі і лекі да спазнання саміх сябе
}

Marzena Marczewska, Ja cię zamawiam, ja cię wypędzam...: Choroba: studium językowo-kulturowe, Kielce 2012, cc. 302

Сфера здароўя і яго падтрымання - адна з самых актуальных і запатрабаваных ва ўсе часы. Стаўленне да хваробы, яе перажыванне і захады па пазбаўленні ад яе, між тым, залежныя ад часу і тыпу культуры. Вопыт народнай медыцыны, рытуальна-магічныя практыкі і вербальная магія слугавалі не аднаму пакаленню і на сёння застаюцца не толькі ў памяці старэйшага пакалення, але і $\ddot{y}$ актуальным бытаванні. У гэтым я пераканалася $\ddot{y}$ час шматлікіх экспедыцый па Беларусі, калі збіраліся матэрыялы для тома "Народная медыцына: рытуальна-магічныя практыкі" з серыі "Беларуская народная творчасць", які выйшаў у 2007 годзе і прадэманстраваў надзвычайнае багацце рытуальных захадаў па лекаванні шматлікіх немачаў. Вывучэнне іх у параўнальным аспекце, а таксама даследаванне светапогляднага падмурку з неабходнасцю вымагае звароту да традыцый суседніх. I вось апошнія гады з'явілася цудойная магчымасць супаставіць беларускі матэрыял з бліжэйшым суседскім - польскім.

У Кельцэ выйшла манаграфія Мажэны Марчэўскай "Я цябе замаўляю, я цябе выганяю" ... Хвароба: моўна-культурныя штуды”, падрыхтаваная у асадах этналінгвістычнай люблінскай школы пад кіраўніцтвам прафесара Ежы Бартміньскага. Даследаванне абапіраецца на чыннікі кагнітыўнай дэфініцыі і ажыццяўляецца ў рэчышчы рэканструкцыі моўнай карціны свету. Крок за крокам прасачыўшы канцэптуалізацыю хваробы у польскай мове і культуры, даследчыца падыходзіць да важкіх тэарэтычных высноў адносна ўнутранай логікі лекавальнага рытуалу.

Этнамедыцынскія веды прадстаўлены ў даследаванні ў самых розных формах - не толькі моўных адзінках розных узройняў, але і $\ddot{y}$ фальклорных тэкстах розных жанраў, у рытуалах, артэфактах і г.д. Магічна-рытуальная лекавальная практыка, замоўна-заклінальная традыцыя і этнамедыцынская наменклатура паўстаюць як пэўны культурны тэкст, утвораны са значнай колькасці прыватных парадыгмаў, якія несумненна карэлююць між сабою і ў значнай ступені абапіраюцца на адзіны семіятычны фон народнай культуры.

У першым - тэарэтычным - раздзеле прадстаўлена тлумачэнне асноўных паняццяй працы: моўная карціна свету, народная медыцына, медыцынская антрапалогія. Тут жа падрабязна, з веданнем справы падаецца гісторыя даследавання этнамедыцынскіх ведаў у Польшчы з цікавымі і вельмі інфарматыўнымі экскурсамі ўласна ў гісторыю народнага лекавання на польскіх землях. Важкім у канцэптуальна-тэарэтычным плане выступае раздзел, прысвечаны даследаванню вербальнага складніку лекавальных рытуалаў.

Раздзел другі "Хвароба ў польскай мове і культуры" прысвечаны канцэптуалізацыі хваробы, як гэта ӱвасобілася ва ўласна лексеме (назвы хвароб, сімптомаў, аб'ектаў і суб'ектаў рытуалу і пад.), этымалогіі і ўнутранай форме слоў, слойнікавых дэфініцыях і метафарычных выкарыстаннях, фразеалагізмах, формулах заклінанняў. Разумеючы, што правесці несупярэчлівую класіфі- 
кацыю хвароб у традыцыйнай карціне свету надзвычай складана, у параграфе "Віды хвароб" усё ж чакалася падагульненне і прапановы адносна народнай рубрыкацыі немачаў. А вось заўвага аўтаркі адносна прыкладання да кожнай хваробы наймення gościec надзвычай паказальная, бо актуалізуе істотныя рысы канцэптуалізацыі хваробы ў цэлым, якая сама па сабе пачынае ўспрымацца як госць у чалавека. Такі акцэнт на абмежаваны час прабывання ў целе заканамерна падводзіць да надзеі і чакання практычна абавязковага яе "ад'езду".

Як вынікае з кнігі, хвароба ў польскай традыцыі канцэптуалізуецца перадусім як штось матэрыяльнае (рэч, цяжар, дол), але разам з тым і як істота жывая, адпаведна, цела чалавека становіцца не толькі ўмяшчальняю, але і полем бітвы (с. 64). Назвы, іх этымалогія (што між іншага падводзіць да думкі аб тлумачэнні здаровага чалавека праз супастаўленне яго з дрэвам), табуізаванне, падае класіфікацыю, тлумачыць захады на прадухіленне хваробы, прычыны, апісвае постаці самой хваробы і нават падае сціслую характарыстыку лекараў. Дасціпна пададзена характарыстыка спосабаў пазбаўлення ад хваробы, час, месца і патрэбныя ў рытуале прадметы і субстанцыі. А вось шматлікі беларускі матэрыял дапаўняе сцвярджэнне М. Марчэўскай аб тым, што этыялогія хваробы зводзіцца да чынніку знешняга, звычайна не звязанага з дысфункцыяй самога цела (с. 81), бо ў шэрагу выпадкаў у народнай свядомасці хвароба тлумачыцца як "узбунтаванне" уннутраных органаў або субстанцый.

Моўны аспект працы выглядае самым прапрацаваным, аўтарка дэманструе лексемы сферы абраных этнамедыцынскіх практык 3 максімальнай паўнатой, старанна ўпарадкаваўшы і змясціўшы ў светапоглядна-рытуальныя кантэксты. У слове і праз слова народ выказвае прычыны хвароб, іх дыягназаванне, прафілактыку і лекаванне.

Мабыць, маючы на ўвазе найменне адной з немачаў як plica polonica спецыфічна польская хвароба, першы культурна-моўны партрэт прысвечаны каўтуну. У гэтым надзвычай цікавым раздзеле падаюцца шэраг назваў, фразеалагізмаў з кампанентам-абазначэннем немачы, этымалогія, уяўленні пра кайтун, адлюстраваныя ў мойных, тэкставых і этнаграфічных дадзеных. Наогул, семіятычны тэкст каўтуна мог бы стаць добрай нагодай для даследавання кшталтавання медыцынскай думкі ўвогуле. У Польшчы каўтун пачаў пісьмова дакументавацца з XVI стагоддзя. Ад найдаўнешых часоў лекары ў поглядах на каўтун дзяліліся на дзве катэгорыі: адны сцвярджалі, што збітыя у камяк валасы і адпаведны стан арганізма па праўдзе ёсць хваробаю, sui generis, другія зводзілі каўтун адно да праяваў занядбанасці, антыгігіенічнасці, лічылі, што каўтун бывае ад нечасання валасой, уплятання ў іх клейкай субстанцы, што можна штучна сфабрыкаваць.

На канкрэтных запісах прыводзіцца выснова аб тым, што каўтун уласцівы кожнаму чалавеку, што гэта немач, якая прыхаваная ў целе, але пры спрыяльных абставінах выходзіць вонкі у сплеценых валасах, высыпках. Каўтуну прыпісваецца самастойнае існаванне, у аповядах вясковага люду ён паўстае як істота са сваім грозным характарам, запатрабаваннямі, яму улласцівыя розныя псіхічныя станы (злуецца, цешыцца і інш.), з ім магчымая пэўная камунікацыя. Каўтун нібыта сам перамяшчаецца $з$ месца на месца і выдае нейкія гукі, пішчыць. Бачылі, кажуць, як выскачыў з хаты і асеў на верхалінах растуча- 
га збожжа ды, укрыўджаны, пішчаў (с. 131). Палякі верылі ў існаванне д'ябла каўтунаватага, што сядзіць у сплеценым жмутку валасоў, таму адцінанне яго адбываецца з выкананнем шэрагу правілай, пры адорванні грашыма і хлебам. Цікава, нават у межах самога цела каўтун нібыта ўступае ў пэўныя стасункі з залатніком, можа з ім загневацца (с. 130). У такім выпадку актуалізуецца анімізацыя і антрапамарфізацыя хваробы, якая тут увасабляецца ў тыповым для чалавека імкненні засваення небяспечнай з'явы побач з уяўленнем яе на сваё падабенства.

У якасці найбольш пашыранай прычыны каўтуна М. Марчэўска называе веру $\ddot{y}$ звіванне яго $\ddot{y}$ выніку чарай, праклёнаў, злой волі іншай істоты. Радзей гэта інструмент для вывядзення хваробы вонкі або вынік няспойненых прагненняў. Сярод істотаў, што насылаюць/выклікаюць каўтун, называюцца чараўніцы, гл. нават іх назву ў кашубаў - kåłtunki (c. 128). Усе названыя прычыны прысутнічаюць і ў беларускіх уяўленнях, хоць апошняе стагоддзе на першы план у якасці асноўнай прычыны выходзіць моцны пярэпалах, стрэс, перажыванні. Сярод іншых адрозненняў можна пазначыць такую дэталь, што у беларусай не зафіксавана называнне кайтуном венерычных хваробаў.

Да дробязяў супадае падрабязна распісанае адцінанне сплеценых валасоў і наступнае з імі абыходжанне. Адметна, што асабліва дзейсным у польскай культуры ўважалася адціненне ў святым месцы, дзе звычайна адбываліся чыннікі экзарцызму. Цікавыя звесткі пра тое, што нават месца ў касцёле Панны Марыі ў Кракаве ўбаку ад так званай брамкі было складам каўтуноў. Сярод іншых сакральных месцаў узгадвае аўтарка і беларускія Жыровічы. Вербальныя і невербальныя лекавальныя захады падпарадкаваны адной мэце - выдаленню хваробы з цела. Гэтая інтэнцыя рэалізуецца ў часе рытуалу, у якім слова ўзмацняе экспрэсію жэстаў, пры выкананні сімвалічных чыннасцяў, якія падкрэсліваюць разуменне хваробы як істоты, якой варта злажыць ахвяру, каб не абразіць; прысутная і ідэя фізічнага аддзялення немачы ад хворага (з сярэдзіны цела вонкі) і адпраўлення ў чужую прастору (дзе хвароба і мусі быць) (c. 148-149).

Раздзел 4 "Зараза - моўнае засванне страху перад хваробай" прысвечаны хваробам эпідэмічным, якія у с сваім эмацыянальным - раптойнасць, гвалт, хуткасць распайсюджання і значны ўрон - паўстаюць у народнай свядомасці як кара боская. У якасці важкага для канцэптуалізацыі хваробы аўтарка вылучае кашубскае найменне роšеdło (с. 156). Менавіта як пошасць вядомыя эпідэмічныя хваробы ў беларусай, паралелі і супадзенні знаходзіць працяг у замовах і рытуальных практыках. Супадаюць і беларускія і польскія аповяды 3 персаніфікацыяй хваробы ў выглядзе маладой дзяўчыны. Асабліва цяжкім для разумення нашым продкам было тое, як пераносіцца пошасць і што яе выклікае, бо менавіта зараза - тая хвароба, якая прыходзіць невытлумачальным чынам, 3 паветрам, і нішчыць людзей (жывёл). Натуральным таму стае метафарыацыя, анімізацыя, персаніфікацыя і дэманізацыя вобразу павальных хваробаў. Адам Міцкевіч у сваім "Конрадзе Валенродзе" паэтызуе заразу на Літве як дзяўчану з хусткай у руках. Для папярэджання эпідэміі і ад яе пазбаўлення і палякамі, і беларусамі аднолькава практыкавалася абворванне граніц, выкарыстанне агню, асабліва жывога, абясшкоджанне небяспечных памерлых, 
архаічны звычай выкарыстання конскага чэрапу, закопванне жывымі людзей і зверанят.

Наступны раздзел мае паказальную назву: «Zegnám cie uroku dziewięć razu do roku... Сурокі як з'ява мовы і культуры". Справядліва зазначыўшы, што сурокі ёсць феноменам на мяжы медыцыны і дэманалогіi (с. 191), М. Марчэўска падрабязна аглядае ўвесь спектр як моўных, так і магічна-рытуальных фактаў, звязаных з нядобрым уздзеяннем злога вока на каго-, што-небудзь. Варта заўважыць, што у полі зроку даследчыцы застаецца і сацыяльны кантэкст з'явы, бо асоба і дзейнасць чараўніцы наўпрост улучаліся ў развязанне і вырашэнне канфліктаў унутры грамады. Раздзел, прысвечаны сурокам, можна разглядаць як энцыклапедычны збор, скрупулёзна раскласіфікаваны, пададзены ў суправаджэнні каментарой вучоных з розных сфераў гуманітарыстыкі. Наогул, хацелася б падкрэсліць самастойную вартасць спасылак, якія ўяўляюць сабой надзвычай прэзентатыўную падборку каментароў і цытат адносна таго ці іншага складніку рытуалу.

Перад намі поўны, добра дакументаваны кампендыум фактаў. Цікава, аднак, польскі матэрыял па рытуальным лекаванні сурокай мае $\ddot{y}$ беларусай не тое што паралелі, але адпаведнікі, у бальшыні выпадкаў літаральныя. Больш разыходжанняй на ўзроўні вербальнай магіi. Безумоўна, мае значэнне фактар суседства, але напрошваецца выснова і пра унніверсальны характар многіх схем, згодна з якімі разгортваюцца канкрэтныя захады ў народаў, што жывуць у прыкладна падобных ландшафтна-кліматычных умовах. Рытуальна-магічнае лекаванне - адкрытая, але абмежаваная стабільным наборам мадэляў сістэма ўяўленняў, рытуалаў і іх вербальнага выяўлення ці суправаджэння; стратэгіi лекавання на шкале мадальнасцяў разгортваюцца ад просьбы да пагрозы, семантычны спектр вылучае такія вузлавыя моманты як выяўленне, выдаленне, знішчэнне, раздзел, абмен, дыялог і інш.

Застаецца пашкадаваць, што такога падрабязнага даследавання трапілі толькі тры немачы, прычым ці не самыя пашыраныя і добра распрацаваныя у польскай традыцыі. Але даследчыкі атрымалі выдатны ўзор для далейшай працы.

Некалькі нечаканым і даволі спрэчным падаецца параўнанне лекавальнага рытуалу з перформансам (с. 272), надта розныя гэта формы як у фармальным, так і сэнсавым напаўненнях. Рытуал не можа быць перформансам па вызначэнні, бо апошні - варыянт гульні і вымагае наяўнасці гледачоў. Прынцыпова адрозніваецца і прагматыка гэтых дзеяў.

Натуральна, даследаванню замой можна было б прысвяціць асобную манаграфію, ды і падрабязнае аналізаванне вербальнай магіi не ўваходзіла ў задачы данай кнігі. Між тым цэлы раздзел аказаўся прысвечаны якраз слову - "Слова ў лекаванні. Народны медыцынскі рытуал". М. Марчэўска аглядае перадусім найбольш праблематычныя моманты гэтай сферы - пытанні тэрміналогіi, суадносінаў магіi і рэлігіi, разглядае замову ў асадах тэорыі камунікацы, аналізуе перфарматыўнасць замоўнага акту. Ілюструюць разважанні тэксты замоў, сабраныя з розных крыніц, перадусім XIX стагоддзя.

Ахоп фактычнага матэрыялу з польскамоўных крыніц апошніх 2-х стагоддзяў падаецца надзвычай прадстайнічым, у даследчае поле трапілі і апісанні 
народнай медыцыны суседніх ўкраінцаў (гл. працы С. Шпіталя і Ю. Талькі-Грынцэвіча. Заўважнае месца займаюць і палявыя запісы самой аўтаркі, а таксама яе студэнтай, што дазваляе не толькі прасачыць трансфармацыю даўніх вераванняў, але і сцвердзіць актуальнасць многіх з іх і сёння.

Здароўе і хваробы ў манаграфіі даследаваны як ментальныя катэгорыі, што падвергліся вербалізацыі і пазамоўнай сімвалізацыі. Разгортванне аналізу у рэчышчы канцэпцыі культурна-моўнай карціны свету, пад якой разумеецца будзённае ўспрыманне рэчаіснасці, дазволіла паглядзець на звычаі, абрады, вераванні, артэфакты, моўныя адзінкі як на адзін тэкст, у якім кожны са складнікаў адцяняе семантычныя грані іншага.

У заключэнне хацелася б павіншаваць паважанага аўтара з грунтойным даследаваннем, а нас, яго чытачоў, з магчымасцю паглыбіцца ў багаты дзівосны свет народнай медыцыны польскага народа.

Тачияна Валодзіна Мінск 